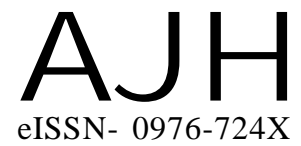

Received : 10.09.2016

Revised : 03.10.2016

Accepted : 17.10 .2016

Members of the Research Forum

Associated Authors:

${ }^{1}$ Department of Horticulture, Assam Agricultural University, JORHAT (ASSAM) INDIA

${ }^{2}$ ICAR Research Complex for NEH Region, UMIAM (MEGHALAYA) INDIA
THEASIAN JOURNALOF HORTICULTURE

Volume 11 | Issue 2 | December, 2016 | 269-274

Visit us -www.researchjournal.co.in

DOI : 10.15740/HAS/TAJH/11.2/269-274

RESEARCH PAPER

\title{
Quality and shelf-life of ready to use brined ginger (Zingiber officinale Rosc.) slices
}

\section{S. PUN ${ }^{1}$, M. NEOG AND BIDYUT C. DEKA ${ }^{2}$}

ABSTRACT : Ginger (Zingiber officinale Rosc.) is one of the widely grown commercially important spices of North East India. Storage of fresh ginger for more than one month is problematic due to severe weight loss and sprouting. The present study was conducted to preserve the peeled ginger slices in acidified brine solution in plastic containers at ambient condition. The ginger rhizomes of Bhola variety harvested at 270 days after planting was found better for preservation of ginger slices of 1.5-2.0 mm thickness in brine. The ginger slices treated with 9 per cent brined solution acidified with 2 per cent citric acid and potassium metabisulphite and benzoic acid $50 \mathrm{ppm}$ each as preservative resulted in better retention of biochemical qualities like crude protein (5.67\%), total soluble carbohydrate (12.89\%), oleoresin $(4.17 \%)$ with better organoleptic qualities and no microbial growth after 180 days of storage. The ginger slices could be safely stored up to 180 days. The brined ginger slices may serve as substitute for fresh ginger during the lean period.

KEY WORDS : Ginger, Brine, Crude protein, Oleoresin, Organoleptic, Miocrobial growth 